ГORIGINAL ARTICLE

Volume 16 Supp 12021

DOI: 10.21315/aos2021.16.s1.6

ARTICLE INFO

Submitted: 02/03/2021

Accepted: 27/05/2021

Online: $22 / 09 / 2021$

\section{Irradiation Time of Photodynamic Therapy to the Number of Lactobacillus acidophilus}

\author{
Sri Kunarti, Nunik Nuraini", Farida Widhi Astuti, Cecilia GJ Lunardi, \\ Lulytha Rahmanike Putri
}

Department of Conservative Dentistry, Faculty of Dental Medicine, Universitas Airlangga, Kota Surabaya, fawa Timur 60132, Indonesia

*Corresponding author: nuraini.nunik@gmail.com

To cite this article: Kunarti S, Nuraini N, Astuti FW, Lunardi CGJ, Putri LR (2021). Irradiation time of photodynamic therapy to the number of Lactobacillus acidophilus. Arch Orofac Sci, 16(Supp.1): 33-36. https://doi.org/10.21315/aos2021.16.s1.6

To link to this article: https://doi.org/10.21315/aos2021.16.s1.6

\begin{abstract}
Lactobacillus acidophilus (L. acidophilus) is one of the etiological agents for dental caries and dominant in the deep carious lesion. L. acidophilus has also been identified in persistent root canal infection and also related to the failure of endodontic treatment. Photodynamic therapy is a therapeutic process involving the combination of a nontoxic photosensitizer and a light source. The excited photosensitizer reacts with reactive oxygen species (ROS), which induce injury and death of the microorganism. This study aimed to prove the effect of irradiation time of photodynamic therapy to the number of L. acidophilus. Fortytwo Eppendorf tubes were treated with $0.5 \mathrm{ml} \mathrm{L}$. acidophilus distributed into seven groups. Group 1 as the control group received no treatment. Groups 2, 3, 4, 5, 6 and 7 were treated with a combination of $0.5 \mathrm{ml}$ toluidine blue $\mathrm{O}(\mathrm{TBO})$ as a photosensitizer and $630 \mathrm{~nm}$ photoactivated (Fotosan ${ }^{\circledR}$ ) exposure time for $10,20,30,40,50$ and $60 \mathrm{sec}$. Then, all were stored in an incubator of $37^{\circ} \mathrm{C}$ for $48 \mathrm{~h}$. Later, the colony-forming unit (CFU) was counted for each group. There were significant differences in the number of L. acidophilus in CFU of the various irradiation times. The longer the photodynamic therapy irradiation was, the lesser the number of live L. acidophilus became. At $50 \mathrm{sec}$ and 60 sec irradiation, none of the L. acidophilus was found alive.
\end{abstract}

Keywords: Irradiation time; Lactobacillus acidophilus; photodynamic therapy; photosensitizer; Toluidine blue $O$

\section{INTRODUCTION}

Lactobacillus acidophilus (L. acidophilus) is one of causative agents for caries in human teeth because it produces lactic acid as the final result of carbohydrate metabolism. These bacteria are known as lactic acid releaser and tolerant of acid (Safan et al., 2014). This situation allows the bacteria to survive in dental plaque carious lesion and continue to damage the tooth structure (Newman \& van Winkelhoff, 2001; Jafarei \& Ebrahimi, 2011). One of the success factors for endodontic treatment is the elimination of pathogenic bacteria. The presence of necrotic tissue and bacteria may cause the persistence of infection in root canals. Root canal complexity structure is the major problem to eliminate the pathogenic bacteria (Safan et al., 2014). Irrigation solution alone is considered to be less effective in eliminating certain pathogenic bacteria in root canals that are difficult to reach. Bacteria left in the root canals can penetrate the dentinal tubules to a depth of $1 \mathrm{~mm}$, while the irrigation disinfection materials can only reach to a depth of $0.1 \mathrm{~mm}$ (Hakimiha et al., 2014). 
Photodynamic therapy is an alternative method to eliminate bacteria in the root canals with its antimicrobial effect. Several studies reported that photodynamic therapy appropriation can reduce the number of gram-positive and negative pathogenic bacteria in the oral cavity. Utilisation of photodynamic therapy in root canal treatment gave significant result in reducing the number of bacteria, and its effectiveness increased seven days after treatment (Hirais \& Al-Huwaizi, 2013). The effectiveness of photodynamic therapy depends on the level of strength, duration, tissue light absorption, the root canal shape and the distance of device tip to the target cells (Hirais \& Al-Huwaizi, 2013; Xhevdet et al., 2014).

\section{Materials and Methods}

The research was an experimental in vitro model utilising the L. acidophilus culture as samples. Culture preparation was taken by micropipette and was put in 42 Eppendorf tubes (Eppendorf, Hamburg, Germany) treated with $0.5 \mathrm{ml}$ L. acidophilus. The Eppendorf tubes were distributed into seven groups and each group was consisted of six samples. Photodynamic therapy used in the research was a device consisting of $0.5 \mathrm{ml}$ Toluidine blue $\mathrm{O}$ (TBO) liquid as the photosensitizer and LED light with a wavelength of $630 \mathrm{~nm}$ as the photoactivation (FotoSan ${ }^{\circledR}$, CMS Dental APS, Copenhagen Denmark).

Group 1 was L. acidophilus in Eppendorf tube with no photosensitizer and no exposure irradiation (negative control). The other groups (Groups 2 to 7 ) had L. acidophilus in Eppendorf tube treated with $0.5 \mathrm{ml}$ photosensitizer and was left for $2 \mathrm{~min}$. They were then irradiated with FotoSan as follows: Group $2=10$ sec; Group $3=20$ sec; Group $4=30$ sec; Group $5=40$ sec; Group $6=50 \mathrm{sec}$; and Group $7=60 \mathrm{sec}$. Afterwards, $0.1 \mathrm{ml}$ was taken from each group using micropipette, was put, and levelled by spreader to all surface of medium in petri dish nutrient agar, then incubated for $48 \mathrm{~h}$ at $37^{\circ} \mathrm{C}$ in the anaerobic atmosphere.
Later, the colony-forming unit (CFU) was counted for each group using the Quebec colony counter (New Brunswick Scientific Co., New Brunswick, USA) to obtain the results.

\section{RESULTS}

Data was analysed with descriptive test and presented in Table 1. The Shapiro-Wilk test was used as the normality test. Groups 1, 2, 3,4 and 5 have $p>0.05$ and thus the data is normally distributed. Whereas Groups 6 and 7 could not be determined as the number of bacteria was zero. On the other hand, the data did not have homogeneous variations as the Levene test obtained was $p=0.003$ $(p<0.05)$. As the data were normally distributed, a Kruskal-Wallis test was performed and there were significant differences, $p=0.000(p<0.05)$, between the number of bacterial colonies throughout the group after being treated. From MannWhitney test, it was revealed that there was significant difference for comparison among groups $(p<0.05)$, except for Groups 6 and $7, p=1.000(p>0.05)$. This is because the number of bacteria was zero in both groups.

Table 1 Mean and standard deviation (SD) for the number of L. acidophilus

\begin{tabular}{cccc} 
Group & Irradiation time (sec) & Mean & SD \\
\hline 1 & 0 & 114.70 & 1.472 \\
2 & 10 & 18.00 & 0.894 \\
3 & 20 & 14.67 & 1.033 \\
4 & 30 & 13.00 & 1.414 \\
5 & 40 & 8.50 & 1.049 \\
6 & 50 & 0.00 & 0.000 \\
7 & 60 & 0.00 & 0.000 \\
\hline
\end{tabular}

\section{DISCUSSION}

Photodynamic works as a combination of photosensitizer and light. In the case of photosensitizer and light that are used separately, no antimicrobial effect is obtained. Photosensitizer material used 
with light can reduce the number of bacteria (Lins et al., 2015; Mohammadi \& Azarpazhooh, 2015). The rays produced from photodynamic therapy can reach the cavity and the depth of dentine tubules up to $0.5 \mathrm{~mm}$ to $1.5 \mathrm{~mm}$, which is difficult to be reached by irrigation of disinfection solution. The photodynamic therapy rays have no toxic content and high degree of selectivity to kill bacteria without damaging host cells (López-Jiménez et al., 2015). The photodynamic therapy device used in the present study, FotoSan utilises red light with a wavelength of $630 \mathrm{~nm}$ and photosensitizer TBO. The TBO is activated by the red light to produce reactive oxygen species (ROS) and cause oxidation that damages the bacterial cell structure (Hopp \& Biffar, 2013; Xhevdet et al., 2014; Diogo et al., 2015).

Light absorption by photosensitizer is a photophysical process to produce ROS and singlet oxygen, which takes place when the photosensitizer molecule has an electron configuration in a stable state (ground state) and absorbs photon light. After absorbing the light, the electron configuration becomes unstable (excited state). From the excited state, photosensitizer can return to a ground state if it loses energy or becomes a triplet state if it continues to get enough energy. Interactions that occur between excited oxygen and biological systems such as bacterial cells will damage the cell's system and structure. This shows the importance of irradiation time to produce ROS so that it can reduce the number of bacteria (Dai et al., 2012).

In the present study, the sample was irradiated with time intervals of 10, 20, $30,40,50$ and $60 \mathrm{sec}$ to get the average number of $L$. acidophilus bacteria. The selection of these times interval was based on the available buttons on the FotoSan tool that are set at $10 \mathrm{sec}$ and $30 \mathrm{sec}$. In Group 2, the $10 \mathrm{sec}$ irradiation still showed the presence of bacteria with an average of 18 colonies. This is not compatible with the protocol instructions of using the FotoSan tool for caries treatment which states that irradiation is carried out for 10 seconds. The average number of $L$. acidophilus bacteria after irradiation of 10,20, 30 and $40 \mathrm{sec}$ still showed the presence of $L$. acidophilus colonies. However, in the $50 \mathrm{sec}$ and $60 \mathrm{sec}$ irradiation, the average number of colonies is zero. This could be due to the DNA damage, the cytoplasmic membrane damage, or the bactericide effect of photodynamic therapy during the irradiation (Lins et al., 2015).

\section{CONCLUSION}

The longer the photodynamic therapy irradiation was, the lesser the number of live L. acidophilus became. At $50 \mathrm{sec}$ and $60 \mathrm{sec}$ irradiation, none of the L. acidophilus was found alive.

\section{REFERENCES}

Dai T, Fuchs BB, Coleman JJ, Prates RA, Astrakas C, St Denis TG et al. (2012). Concepts and principles of photodynamic therapy as an alternative antifungal discovery platform. Front Microbiol, 3: 120. https://doi.org/10.3389/fmicb.2012.00120

Diogo P, Gonçalves T, Palma P, Santos JM (2015). Photodynamic antimicrobial chemotherapy for root canal system asepsis: A narrative literature review. Int $\mathcal{F}$ Dent, 2015: 269205. https://doi.org/ $10.1155 / 2015 / 269205$

Hakimiha N, Khoei F, Bahador A, Fekrazad R (2014). The susceptibility of Streptococcus mutans to antibacterial photodynamic therapy: A comparison of two different photosensitizers and light sources. f Appl Oral Sci, 22(2): 80-84. https://doi .org/10.1590/1678-775720130038

Hirais MC, Al-Huwaizi HF (2013). Evaluation of antibacterial action of photosensitizer solution activated by diode lamp and three intracanal medicament (in vitro study). f Baghdad Coll Dent, 25(3): 43-48. 
Hopp M, Biffar R (2013). Photodynamic therapies-blue versus green. Int Mag Laser Dent, 5: 10-25.

Jafarei P, Ebrahimi MT (2011). Lactobacillus acidophilus cell structure and application. Afr f Microbiol Res, 5(24): 4033-4042. https://doi.org/10.5897/AJMR1 1.630

Lins CCSA, Melo ARS, Silva CC, Oliveira JB, Lima GA, Castro CMMB et al. (2015). Photodynamic therapy application in endodontic aerobic microorganisms and facultative anaerobic. In: Méndez-Vilas A (ed.), The Battle Against Microbial Pathogens: Basic Science, Technological Advances and Educational Programs. Badajoz: Formatex Research Center, pp. 559-563.

López-Jiménez L, Fusté E, Martínez-Garriga B, Arnabat-Domínguez J, Vinuesa T, Viñas M (2015). Effect of photodynamic therapy Enterococcus faecalis biofilms. Lasers Med Sci, 30(1): 1519-1526. https://doi.org/10 .1007/s10103-015-1749-y
Mohammadi Z, Azarpazhooh A (2015). Ozone Application in Endodontics. In: Basrani B (ed.), Endodontic Irrigation. London: Springer International Publishing, pp. 221226.

Newman MG, van Winkelhoff AJ (eds.) (2001). Antibiotic and Antimicrobial Use in Dental Practice, 2nd edn. Chicago: Quintessence Publishing Co., pp. 25-29.

Safan A, Youssef T, Zaazou MH, Sherein I, ElMoez SIA, El-Shinawy H, Sadony DM (2014). Antibacterial effect of silver and gold nanoparticles and diode laser against Lactobacillus acidophilus bacteria. Int $\mathcal{F} A d v$ Res, 2(8): 34-38.

Xhevdet A, Stubljar D, Kriznar I, Jukic T, Skvarc $M$ et al. (2014). The disinfecting efficacy of root canals with laser photodynamic therapy. F Lasers Med Sci, 5(1): 19-26. 